\title{
Mineraçãão
}

\section{Production of pellet feed from slimes}

\author{
Produção de pellet feed a partir de lamas
}

\begin{abstract}
Elias Fonseca Castro
Research Engineer, Samarco.

elias.fonseca@samarco.com
\end{abstract}

\section{Antonio Eduardo Clark Peres Professor, \\ Universidade Federal de Minas Gerais. aecperes@demet.ufmg.br}

\begin{abstract}
Resumo
A recuperação de minerais portadores de ferro, a partir de rejeitos de beneficiamento de minérios de ferro, representa um desafio quanto à sustentabilidade do estágio preliminar da siderurgia. Essa investigação abordou a produção de concentrado de minério de ferro dentro das especificações de pellet feed da Samarco, a partir de amostra representativa do overflow dos ciclones deslamadores $(101,6 \mathrm{~mm}$, 4") do concentrador I da Samarco. Os ensaios incluíram estágios de microdeslamagem e flotação. O método de microdeslamagem desenvolvido mostrou-se eficiente e o concentrado produzido por flotação catiônica reversa apresentou teor de sílica compatível com o exigido para pellet feed.
\end{abstract}

Palavras-chave: Minérios de ferro, flotação de lamas, microdeslamagem.

\begin{abstract}
The recovery of iron bearing minerals from the reject products of the beneficiation of iron ores is a challenge concerning the sustainability of the preliminary stage of iron and steel making. This investigation addressed the production of iron ore concentrate within the specifications of Samarco's pellet feed from a representative sample of the concentrator I desliming cyclone's $(101.6 \mathrm{~mm}, 4$ ") overflow. The experiments included stages of microdesliming and flotation. The developed microdesliming method was efficient and the concentrate produced via cationic reverse flotation presented silica content compatible with pellet feed requirements.
\end{abstract}

Keywords: Iron ores, slimes flotation, microdesliming .

\section{Introduction}

In 2011, Samarco's concentrator I produced $14.2 \times 10^{6} \mathrm{t}$ of pellet feed and $9.9 \times 10^{6} \mathrm{t}$ of reject fraction consisting of flotation tailings and the so-called plant slimes (desliming stage overflow).

Vieira and Peres (2010) developed a process route to beneficiate the tailings from the mechanical machine's flotation circuit. With the implementation of this route, the plant slimes will represent $60 \%$ of the concentrator I metallic losses, strategically rendering the development of a route capable of recovering valuable species contained in this fraction.

Routes for the beneficiation of iron ores flotation tailings and slimes were investigated by Oliveira et al. (2006) and Rocha et al. (2010). The studies by Oliveira et al. (2006) were focused on the fraction $<45 \mu \mathrm{m}$ of Conceição concentrator (VALE) tailings thickener underflow. The major contaminating species were quartz in the size range $>9 \mu \mathrm{m}$ and kaolinite in the size range $<9 \mu \mathrm{m}$. The high contents 
of aluminum and phosphorus in the fine size range rendered necessary the use of a desliming stage in hydrocyclones. The underflow of this stage was submitted to reverse cationic flotation. A rough economic estimate indicated capital expenditure of US\$ $5 \times 10^{6}$ and annual return of US\$ $7 \mathrm{x}$ $10^{6}$. Rocha et al. (2010), investigating the

\section{Materials and methods}

\section{Sampling and sample preparation}

The sample of itabirite ore was composed from increments collected in the global plant slimes pipe during six days, three of them destined for the production of blast furnace pellet feed and the remaining three destined for the production of direct reduction pellet feed.

Each increment (9 drums of $200 \mathrm{~L}$ ) was deslimed (operation designated as microdesliming) to adequate the size distribution and chemical composition of concentration of slimes from Companhia Siderúrgica Nacional - CSN - via column reverse cationic flotation, reached $80 \%$ of metallic recovery and silica content in the concentrate $<1 \%$.

The motivation for the present investigation arose from previous smaller scale internal studies at Samarco (Castro, 2011) aiming at the production of pellet feed from the plant slimes with classification via sedimentation in a $4 \mathrm{~L}$ cell preceding quartz reverse cationic flotation. A decrease in the mineralogical phases bearing alumina, phosphorus, and loss on ignition was achieved in sedimentation, providing selectivity for the subsequent flotation stage. the plant slimes for flotation. Microdesliming was performed in the drums; the product's separation (overflow and underflow) being achieved according to the particles' settling velocity. The technique, illustrated in Figure 1, was adapted from a beaker sedimentation method described by Luz and Lima (2001). The plant slimes were placed in $200 \mathrm{~L}$ drums reaching the volume of $132 \mathrm{~L}(50 \mathrm{~cm}$ of the total height " $\mathrm{H}$ "),

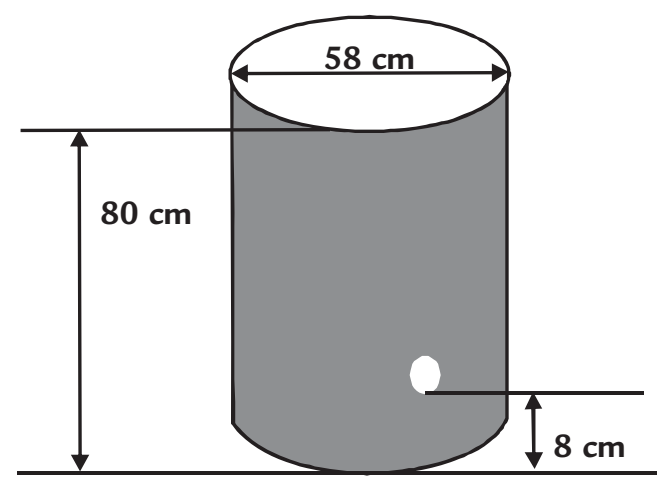

The terminal velocity was determined using the Stokes equation. The cal-

where:

$\mathrm{V}_{\mathrm{t}}=$ particle terminal velocity $\left(\mathrm{m} \cdot \mathrm{s}^{-1}\right)$; $\mathrm{d}_{\mathrm{p}}=$ particle diameter $(\mathrm{m}) ; \mathrm{g}=$ gravity acceleration $\left(\mathrm{m} . \mathrm{s}^{-2}\right) ; \rho_{\mathrm{p}}=$ particle density $\left(\mathrm{kg} \cdot \mathrm{m}^{-3}\right) ; \rho_{\mathrm{L}}=$ fluid density $\left(\mathrm{kg} \cdot \mathrm{m}^{-3}\right) ; \eta=$ fluid viscosity (N.s.m $\left.{ }^{-2}\right)\left(\eta=0.001\right.$ N.s.m ${ }^{-2}$ for water at $20^{\circ} \mathrm{C}$ ).

The following parameters were adopted for the calculation of the terminal velocity $\left(\mathrm{V}_{\mathrm{t}}\right)$ : $\mathrm{d}_{\mathrm{p}}=5 \mu \mathrm{m}$ (hematite, quartz

where:

$\mathrm{S}=$ distance travelled from the liquid surface to the faucet $(\mathrm{m}), \mathrm{H}=$ liquid height $(\mathrm{m}), \mathrm{d}_{\mathrm{i}}=$ diameter of fines of culated terminal velocity provides the time required for a particle of a certain size to

$$
V_{t}=\frac{d_{p}^{2} g\left(\rho_{p}-\rho_{L}\right)}{18 \eta}
$$

and goethite), $\rho_{\text {hematite }}=5,300 \mathrm{~kg} \cdot \mathrm{m}^{-3}$, $\rho_{\text {quartz }}=2,600 \mathrm{~kg} \cdot \mathrm{m}^{-3}, \rho_{\text {goethite }}=3,800 \mathrm{~kg} \cdot \mathrm{m}^{-3}$, $\rho_{\mathrm{L}}=1,000 \mathrm{~kg} \cdot \mathrm{m}^{-3}, \eta=0.001$ N.s.m ${ }^{-2}$.

The calculated terminal velocities for the particles of hematite, quartz, and goethite were: $\mathrm{V}_{\mathrm{t} \text { hematite }}=21.0 \mathrm{~cm} \cdot \mathrm{h}^{-1}$, $\mathrm{V}_{\mathrm{t} \text { quartz }}=7.8 \mathrm{~cm} \cdot \mathrm{h}^{-1}, \mathrm{~V}_{\mathrm{t} \text { goethite }}=13.7 \mathrm{~cm} \cdot \mathrm{h}^{-1}$.

With the distance travelled by the particles being $42 \mathrm{~cm}(\mathrm{H}=50 \mathrm{~cm}$ to $\mathrm{H}$ $=8 \mathrm{~cm}$ ), the span of time required for

$$
R E=1-\left\{1-\frac{s}{H}\left[1-\left(\frac{d_{i}}{d_{p}}\right)^{2}\right]\right\}^{n}
$$

the considered class $(\mathrm{m}), \mathrm{d}_{\mathrm{p}}=$ partition diameter $(\mathrm{m}), \mathrm{n}=$ number of dilution/ sedimentation cycles.

The microdesliming underflow dispersed by hand with the aid of a rod, and the $\mathrm{pH}$ was adjusted to 11 , with an addition of $\mathrm{NaOH}(50 \% \mathrm{w} / \mathrm{v})$. The original percentage of solids (4\% to $6 \%$ ) was kept. The drums were left to rest and after a pre-determined span of time, the supernatant was collected via a faucet at $8 \mathrm{~cm}$ of the total height " $\mathrm{H}$ ". Tap water was then added to the drums to complete the volume of $132 \mathrm{~L}$, and the procedure was repeated twice.
Figure 1

Illustration of the microdesliming drum indicating dimensions and height of the faucet for overflow discharge.

migrate from the liquid surface $(\mathrm{H}=50 \mathrm{~cm})$ to the region below the faucet $(\mathrm{H}<8 \mathrm{~cm})$.

hematite particles larger than $5 \mu \mathrm{m}$ to migrate to the drum region below the faucet is 2 hours.

The removal efficiency (RE) of each class of undue particles $\left(\mathrm{d}_{\mathrm{i}}\right)$, of diameter smaller than or equal to the partition diameter $\left(d_{p}\right)$, is given by equation (2), an infinite number of sedimentations being necessary for a complete separation of the particles with diameter smaller than or equal to $d_{i}$.

fraction constituted the feed of the dispersion and flotation experiments and the microdesliming overflow was a reject product. 


\section{Flotation experiments}

The experiments of quartz reverse cationic flotation were performed in a laboratory Wemco flotation machine. The iron oxide's depressant was cassava starch, supplied by Amafil, gelatinized with sodium hydroxide. The quartz collectors used were etherdiamine TOMAH DA16 30 and ethermonoamine PA 14F-30, both supplied by Air Products.

\section{Results and discussion Drum microdesliming}

Microdesliming in drum was an efficient size classification method. The chemical composition, density, blaine surface area (BSA) of the microdesliming feed and products are presented in Table 1 and the respective size distribution curves

Table 1

Chemical and physical analyses and weight of feed and products of drum microdesliming.

Figure 2

Size distribution of feed and products of drum microdesliming.

Figure 3

Products of the drum desliming.
Eighteen flotation experiments were performed ( 9 conditions in duplicate) for each proportion of etheramine used. The investigated etheramine proportions were: $100 \%$ etherdiamine, $75 \%$ etherdiamine $+25 \%$ ethermonoamine, $50 \%$ etherdiamine $+50 \%$ ethermonoamine, $100 \%$ ethermonoamine, and $75 \%$ ethermonoamine $+25 \%$ etherdiamine. The dosages and $\mathrm{pH}$ values selected for the tests were: (i) cassava starch: $750 \mathrm{~g} / \mathrm{t}, 1000 \mathrm{~g} / \mathrm{t}$, and $1250 \mathrm{~g} / \mathrm{t}$;

(ii) etheramines: $150 \mathrm{~g} / \mathrm{t}, 300 \mathrm{~g} / \mathrm{t}$, and $450 \mathrm{~g} / \mathrm{t}$

(iii) $\mathrm{pH}: 10.5,11.0$, and11.5.

The analyzed response variables were: silica content and iron recovery in the concentrate. are illustrated in Figure 2.

The difference between the BSA of the microdesliming feed and products, and also the differences among the size distribution curves, especially in the fractions below $10 \mu \mathrm{m}$, validate the efficiency of this classification method.

Figure 3 illustrates images of the drum desliming products. The yellow ocher color and the high LOI content in the overflow indicate the significant presence of iron hydroxides.

\begin{tabular}{c|c|c|c|c|c|c|c|c}
\hline Fraction & $\begin{array}{c}\mathrm{Fe} \\
\%\end{array}$ & $\begin{array}{c}\mathrm{SiO}_{2} \\
\%\end{array}$ & $\begin{array}{c}\mathrm{Al}_{2} \mathrm{O}_{3} \\
\%\end{array}$ & $\begin{array}{c}\mathbf{P} \\
\%\end{array}$ & $\begin{array}{c}\text { LOI } \\
\%\end{array}$ & $\begin{array}{c}\text { Dens. } \\
\left(\mathbf{g} / \mathbf{c m}^{3} \mathbf{)}\right.\end{array}$ & $\begin{array}{c}\mathbf{B S A} \\
\left(\mathbf{c m}^{2} / \mathbf{g}\right)\end{array}$ & $\begin{array}{c}\text { Weight } \\
\mathbf{( k g})\end{array}$ \\
\hline Feed & 49.65 & 19.30 & 3.89 & 0.070 & 5.50 & 3,947 & 10,303 & 367.9 \\
\hline Underflow & 52.90 & 19.11 & 1.88 & 0.053 & 3.09 & 4,203 & 4,987 & 180.9 \\
\hline Overflow & 43.77 & 21.22 & 6.02 & 0.161 & 9.50 & 3,633 & 13,830 & 187.0 \\
\hline
\end{tabular}
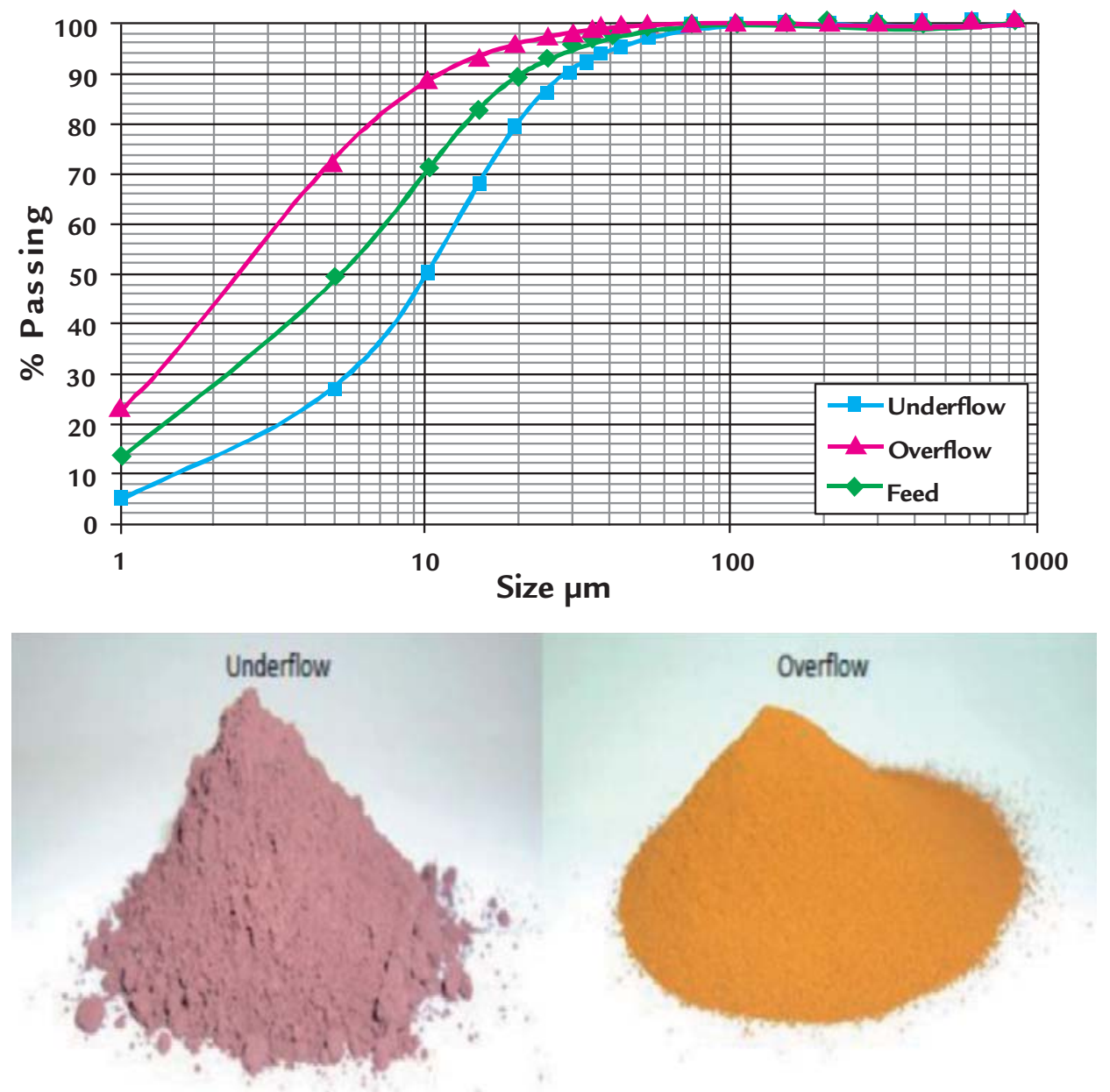


\section{Flotation experiments}

The results are presented as graphs in which the arithmetic mean of values of silica content in the concentrate are plotted for the selected five proportions of ether amines, shown in Figure 4. The curves indicate similar trends. The most efficient condition for silica removal was \#5 and conditions \#6 and \#9 were the least effective.

The collectors, etherdiamine and
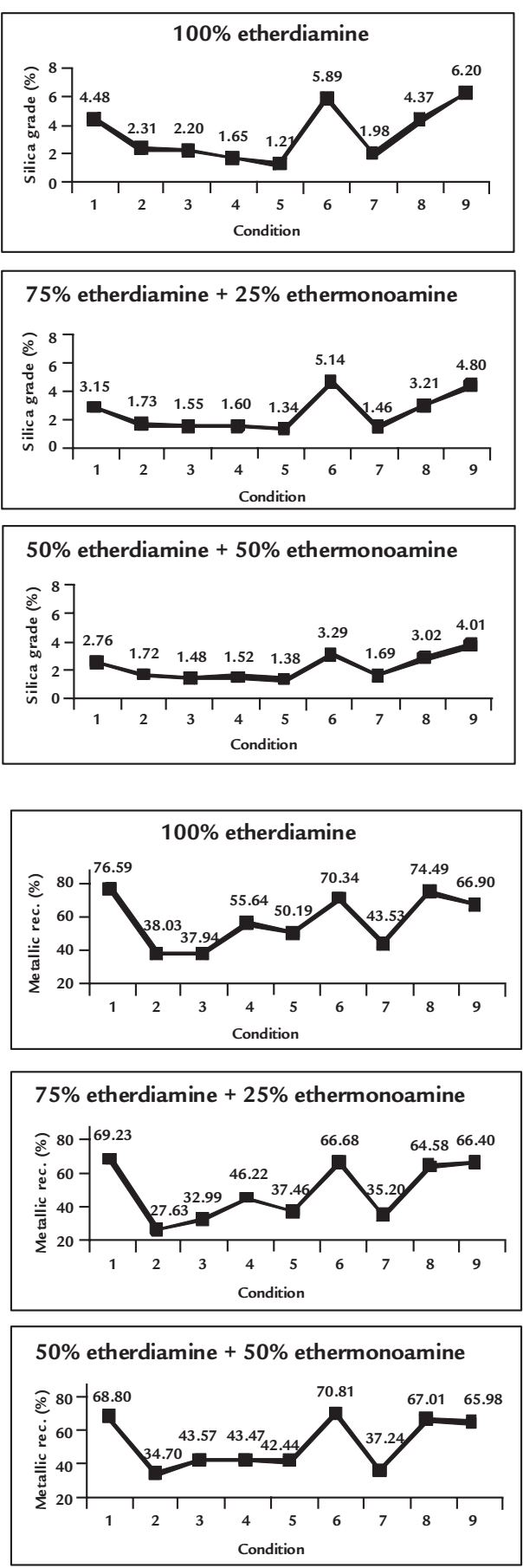

\section{Conclusions}

The drum size classification is an effective microdesliming method, as revealed by the features: differences in ethermonoamine, when dosed individually, yielded the lowest average silica grades in the concentrate, $1.21 \%$ and $1.20 \%$, respectively.

Figure 5 shows arithmetic mean values of the metallic recovery for the selected five proportions of ether amines. Similar trends for the 9 test conditions were again observed.
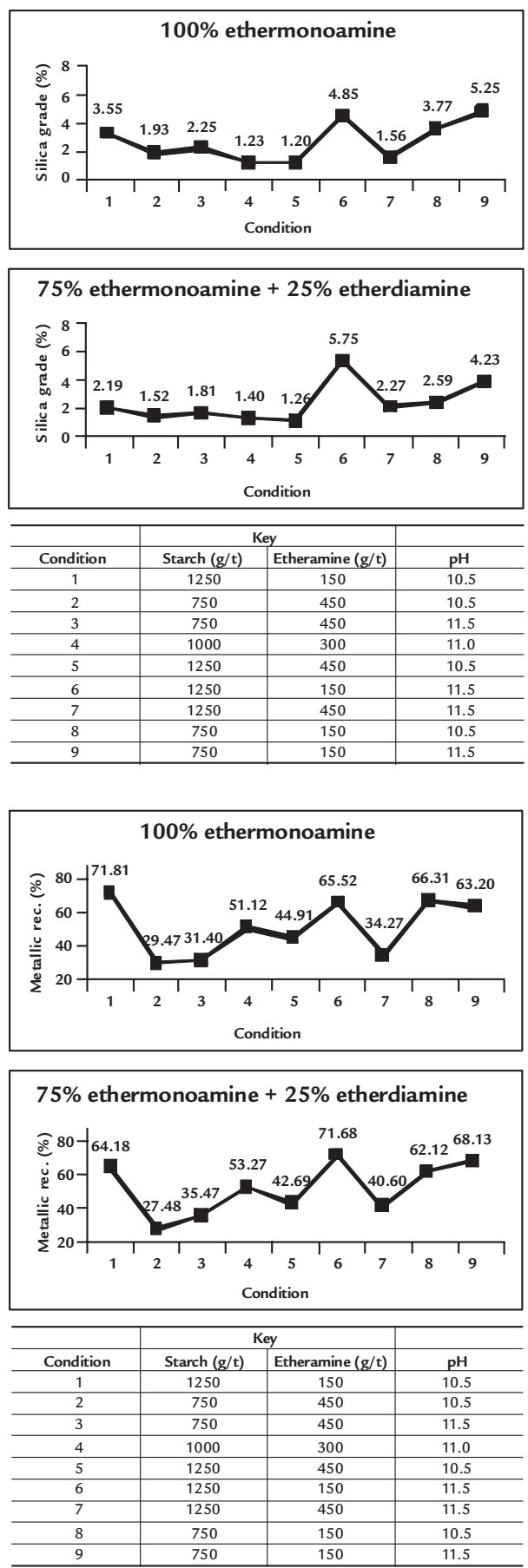

Figure 5

Metallic recovery for different test conditions.

color, size distribution, and blaine surface area between feed and products. Preferential partitions of iron to the
The proportion $100 \%$ etherdiamine yielded the highest metallic recoveries for 6 tested conditions (\#1, \#3, \#4, \#5, \#7, and \#8). The proportion $75 \%$ ethermonoamine $+25 \%$ etherdiamine yielded the highest metallic recoveries for 2 tested conditions (\#6, and \#9) and the proportion $100 \%$ ethermonoamine yielded the highest metallic recoveries for only 1 tested condition (\#2).

\section{Figure 4}

Silica content in the concentrate for different test conditions. underflow and of clay minerals, bearing aluminum and phosphorus are also relevant aspects. 
The laboratory scale flotation of the microdesliming underflow was selective. The best flotation condition was cassava starch dosage 1,250 g/t, etherdiamine individually dosed at $450 \mathrm{~g} / \mathrm{t}$, and $\mathrm{pH} 10.5$, yielding mean arithmetic values of $1.21 \%$ for silica content in the concentrate and $50.19 \%$ for the metallic recovery.

\section{References}

CASTRO, E.F. Sedimentation tests and flotation with plant slimes. Internal Report Samarco, 2011. (In Portuguese).

LUZ, J.A.M., LIMA, R.M.F., Size analysis via technique based on gravity sedimentation: Stokes Law. REM - Revista Escola de Minas, v. 54, n. 2, p. 155159, 2001. (In Portuguese).

OLIVEIRA, P.S., ARAUJO, A.C., CALIXTO, M.F., COSTA, J.B., PAULA, N.N. Process routes for the recovery of iron fines from the slimes thickener underflow of Conceição concentrator. In: SIMPÓSIO DE MINÉRIO DE FERRO, 7. Proceedings... Ouro Preto, ABM, p. 770-779, 2006. (In Portuguese).

ROCHA, L., CANÇADO, R.Z.L., PERES, A.E.C. Iron ore slimes flotation. Minerals Engineering, v. 23, n. 11-13, p. 842- 845, 2010.

VIEIRA, M.G., PERES, A.E.C. Pellet feed production via concentration of flotation tailings. Minerals \& Metallurgical Processing, v. 27, n. 3, p. 124-128, 2010.

Artigo recebido em 04 de janeiro de 2013. Aprovado em 05 de abril de 2013. 